УДК 006.85

\title{
PLANNING AND SCHEDULING \\ AS THE BASIS OF EFFECTIVE ACTIVITY OF MODERN DAIRY ENTERPRISES
}

\author{
R. Mirkevich, A. Pupena \\ National University of Food Technologies
}

\begin{tabular}{l} 
Key words: \\
MES \\
APS \\
Advanced Planning \& \\
Scheduling \\
ERP \\
\hline
\end{tabular}

Article history:

Received 06.07.2018

Received in revised form

27.07.2018

Accepted 23.08.2018

Corresponding author:

R. Mirkevich

E-mail:

roman.mirkevich@gmail. com

\begin{abstract}
The paper deals with modern approaches to production planning scheduling system, and their use in dairy production. The place of planning and scheduling functions in the integrated enterprise management system (ERP, MES/MOM) is shown, and the typical hierarchical structure of the planning and scheduling system in its composition is shown. The features of the production planning and scheduling concepts in MRPII, APS and MES-planning and their fundamental difference are presented. A review of recent foreign publications and general approaches to production planning and scheduling, their functioning features at dairy enterprises, and general problems are highlighted. The main approaches, models and methods used for production planning and scheduling at dairy enterprises are highlighted. The most essential problems of production planning and scheduling features and analysis of dairy products with variable recipes and flexible lines are made. It is shown that the integration of planning tasks with the data of enterprise resources in accordance with ISA-95 standards, the interaction of the planning subsystem with the management system of recipes in accordance with ISA-88 standards, these standards, along with a number of others, are the basis of the reference model of components of Industry 4.0 (RAMI 4.0) and have proven themselves at many enterprises in the world. Possible ways of production development for planning and scheduling subsystems during their use with cloud services are shown. An ability to collect data (IoT, IIoT) from any objects in large number and use it both in the analysis and in the study (for example, the neural network) - exactly by itself is very promising.

The article is reviewable and can be useful for computer integrated management systems specialists as well as for production enterprises management, system integrators and vendors.
\end{abstract}

DOI: $10.24263 / 2225-2924-2018-24-4-5$ 


\title{
ОПЕРАТИВНО-КАЛЕНДАРНЕ ПЛАНУВАННЯ ЯК ОСНОВА ЕФЕКТИВНОї ДІЯЛЬНОСТІ СУЧАСНИХ МОЛОЧНИХ ПІДПРИЕМСТВ
}

\author{
Р.М. Міркевич, О.М. Пупена \\ Наиіональний університет харчових технологій
}

У статті розглянуто сучасні підходи до оперативно-календарного планування виробництвом та їх використання у молочному виробнищтві. Показано місие функиій планування в інтегрованій автоматизованій системі керування підприємством (ERP, MES/MOM) i наведено типову ієрархічну структуру підсистеми оперативно-календарного планування в ї̈ складi. Визначено особливості використовуваних конщепџій планування $і$ створення графіків виробництв у MRPII, APS і MES-плануванні та їх принципова відмінність. Зроблено огляд останніх статей зарубіжних видань $і$ виділено загальні підходи до планування та створення графіків виробництв, особливостей їхнього функиіонування на молочних підприємствах, загальні проблеми. Виділені основні підходи, моделі та методи вирішення, щз використовуються при плануванні на молочних підприємствах. Визначено особливості та зроблено аналіз найбільш актуальних проблем планування і створення графіків виробництва иільномолочних продуктів зі змінною рецептурою та гнучкими лініями. Показана необхідність інтеграчії задач планування з даними ресурсів підприємства відповідно до стандартів ISA-95, взаємодії підсистеми планування з системою керування рецептами відповідно до ISA-88. Ці стандарти разом з рядом інших лежать в основі референтної моделі компонентів Iндустрії 4.0 (RAMI 4.0) та вже давно зарекомендували себе на багатьох підприємствах у світі. Показано можливі шляхи розвитку підсистем планування та створення графіків виробничтв при їх використання з хмарними сервісами, можливість збирати дані (IоT, IIоT) з будь-яких об 'єктів у великій кількості та використовувати їх як в аналітиці, так $і$ в навчанні (наприклад, нейромереж).

Стаття має оглядовий характер і може бути корисною спеціалістам 3 комп'ютерно-інтегрованих систем керування, а також керівництву виробничих підприємств, системних інтеграторів і постачальників.

Ключові слова: MES, APS, Advanced Planning \& Scheduling, ERP.

Постановка проблеми. На сьогодні більшість вітчизняних молочних підприємств $\epsilon$ автоматизованими за так званим «клаптиковим» принципом. Поперше, на рівні автоматизованих систем керування технологічними процесами (АСКТП) окремі відділення та лінії автоматизувалися різними розробниками. По-друге, робота автоматизованих систем на рівнях автоматизованих систем керування підприємством (АСКП) та АСКТП, як правило, координується через спілкування персоналу. Тобто з точки зору автоматизації всі підсистеми підприємства функціонують автоматизовано, але автономно, що 
не дає максимально можливих ефектів, які може дати комплексна автоматизація, в якій все підприємство, включаючи підрозділи (ділянки, цеху, служби), на всіх рівнях керування функціонує як єдина система. «Клаптикова» автоматизація охоплює всі основні виробничі і керівні функції на підприємстві, однак вони не узгоджені між собою. Технічно сучасні молочні підприємства вже готові до інтеграції існуючих підсистем, однак є ряд причин, які створюють бар'єри на цьому шляху. Серед них - неочевидність для керівного персоналу цілей інтеграції, неготовність деяких посадових осіб до прозорості, недостатня обгрунтованість з боку інтеграторів тощо.

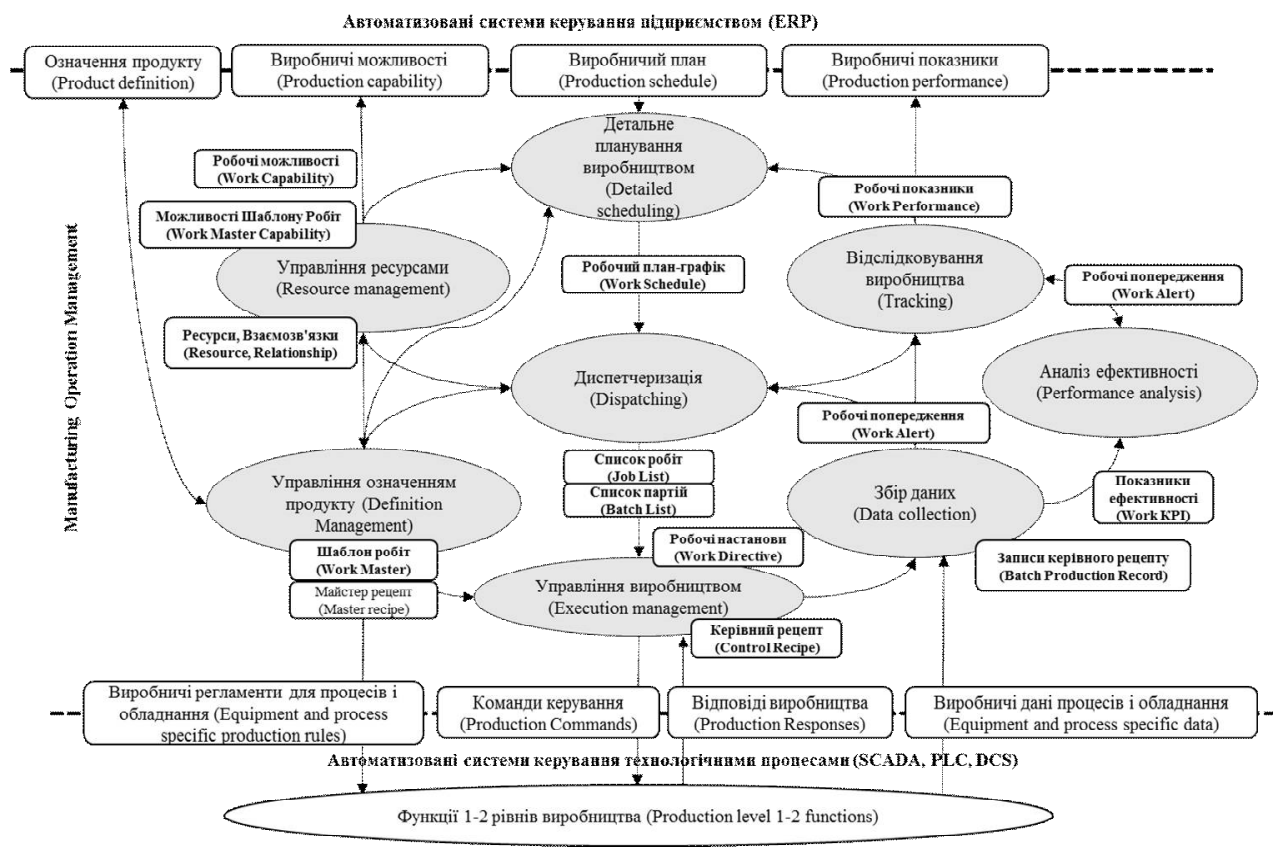

Рис. 1. Функції МOM за стандартом ISA-95

Ефективність функціонування інтегрованої системи на противагу «клаптиковій» автоматизації показана в багатьох працях, зокрема в [1-4]. Усі функції керування виробництвом покладені на рівень MES, який сьогодні прийнято також називати MOM. Хоч межі між визначеннями MES та MOM досить умовні, вважається, що у перелік функцій МОМ входять не тільки керування операціями з виготовлення продукції, а й керування активами. Як відомо, правила інтеграції на рівні функцій і формат представлення інформаційних потоків між ними закріплені в стандартах ISA-95 [5-7] та їхніх відповідниках IEC 6224. Найбільш повно, на нашу думку, взаємодія цих функцій для кожного типу операцій 3 іншими функціями на різних рівнях керування показана на рис. 1, наведеному в частині 3 стандарту ISA-95 та IEC 6224 [6]. Як видно 3 рис. 1, центровими функціями MOM (3-й рівень) є планування, виконання замовлень і контроль за виконанням. Для означення того, який саме продукт необхідно виробляти, у функціональній структурі передбачені 
відповідні функції. Показники якості контролюються через розрахунок ключових показників ефективності (KPI) та їх порівняння із заданими. Усі ці функції МОМ безпосередньо чи опосередковано взаємодіють 3 функціями рівня керування підприємством (ERP, 4-й рівень) та керування технологічними процесами (АСКТП, 1,2-й рівні).

Наведений вище перелік функцій та операцій МОМ необхідний не для всіх видів підприємств, навіть якщо вони мають виробничі майданчики. Однак для підприємств з виробництвом молочної продукції з наведеної вище функціональної структури важко щось «прибрати». Сьогоднішні передові підприємства мають у своєму складі декілька майданчиків для виробництва молочної продукції з різною номенклатурою. При цьому необхідний перелік продукції та об'єми партій формується або корегується за день до дати запланованого виробництва. Гнучкість ліній дає значні переваги при налаштуванні до конкретного продукту, але значно ускладнює процеси планування. Якщо додати сюди необхідність у періодичній зміні номенклатури (рецептури), задачу ефективного планування взагалі неможливо реалізувати. Це реалії сьогодення, в якому світ невпинно рухається в бік Індустрії 4.0, де автоматизоване виробництво під замовлення без участі людини $\epsilon$ необхідною (але недостатньою) умовою.

На більшості вітчизняних підприємств на рівні довгострокового та середньострокового планування в ERP-системах використовуються, як правило, середньостатистичні дані про виробничі потужності та евристичні підходи або ручне формування. Звичайно, що про адаптацію планування під виробничі ресурси та зміну номенклатури можна говорити тільки в минулому часі (коли зміни вже відбулися), а на автоматизацію в ланцюжку поставок та збуту, яка вимагає обізнаності в ресурсах, можна навіть не сподіватися. Щодо оперативного планування, то воно, як правило, проводиться змінним майстром на основі минулого досвіду і практично неавтоматизоване.

Вирішувати проблему ефективності планування очевидно потрібно в двох площинах — теоретичній і практичній.

Аналіз останніх досліджень і публікацій. Структура планування. Найбільш систематизовано і доступно, на нашу думку, сучасні підходи, методи та засоби планування висвітлено в монографії Мауергауса [8]. На сучасних підприємствах планування проводиться на декількох рівнях керування. На рівні АСКП планування, як правило, передбачає вироблення об'ємно-календарних планів на довгострокові та середньострокові горизонти. Ці плани призначені для формування асортименту та кількості виготовлення продукції, закупівлі сировини, керування ланцюжком поставок та іншої фінансової діяльності. На рівні MES/MOM планування передбачає складання розкладу, в якому з використанням конкретних ресурсів (сировини, обладнання, персоналу) створюється конкретна партія продукту. MES-планування оперує годинами, хвилинами (інколи секундами), тоді як на рівні ERP оперують добами, декадами, місяцями.

На рівні ERP прийнято використовувати методи MRPII, які спрямовані тільки на об'ємні плани (без означення ресурсів і астрономічного часу), що не враховують плинний стан ресурсів і незавершеного виробництва [8; 9]. Ефективне ж планування виробництва можливе тільки з урахуванням ресурсів 
та обмежень на всіх рівнях керування. Тому наявність єдиної інформаційної системи підприємства є передумовою ієрархічної підсистеми планування. Між задачами та методами ERP та MES планування $є$ значні відмінності, що ускладнює процес інтеграції цих функцій в єдину узгоджену підсистему. Тому останнім часом популярності набули системи та концепції APS (Advanced Planning and Scheduling). Концепція APS - це прогресивне управління виробничими ресурсами (обладнанням, персоналом тощо) шляхом створення планів виробництва продукції і графіків використання ресурсів (завантаження обладнання, використання матеріалів тощо), а також є розвитком фундаментальних основ, на яких побудовані системи класу ERP. Однією з особливостей концепції $є$ можливість швидко і легко вирішувати такі задачі, як розподіл завдань 3 урахуванням пріоритетів і обмежень, що дає змогу скоригувати виробничий план таким чином, що нові термінові виробничі замовлення будуть додані у вже створений план виробництва. Ця особливість передбачає, що в процесі планування i перепланування у системах, що реалізують концепцію APS, при побудові можливих варіантів плану й розподілу ресурсів для його виконання, широко використовуються сучасні методи оптимізації (від точних математичних до швидких у вирішенні евристичних). Уся діяльність передбачає узгодження 3 керуванням ланцюжком постачань і збуту. Слід зазначити, що концепції, покладені в основу APS-систем, у цей час часто можуть використовуються не лише як окремі системи, а й при створенні спеціалізованих модулів в ERP або MES системах. Тому межі підсистем розмиваються, оскільки концепція APS може лягти в основу функцій планування в системах ERP або MES. На рис. 2 показана структура єдиної інтегрованої інформаційної системи підприємства і підсистеми, які входять до іiі складу. Як видно із структури, APS-система частково перекриває сферу діяльності ERP-систем і MES-систем.

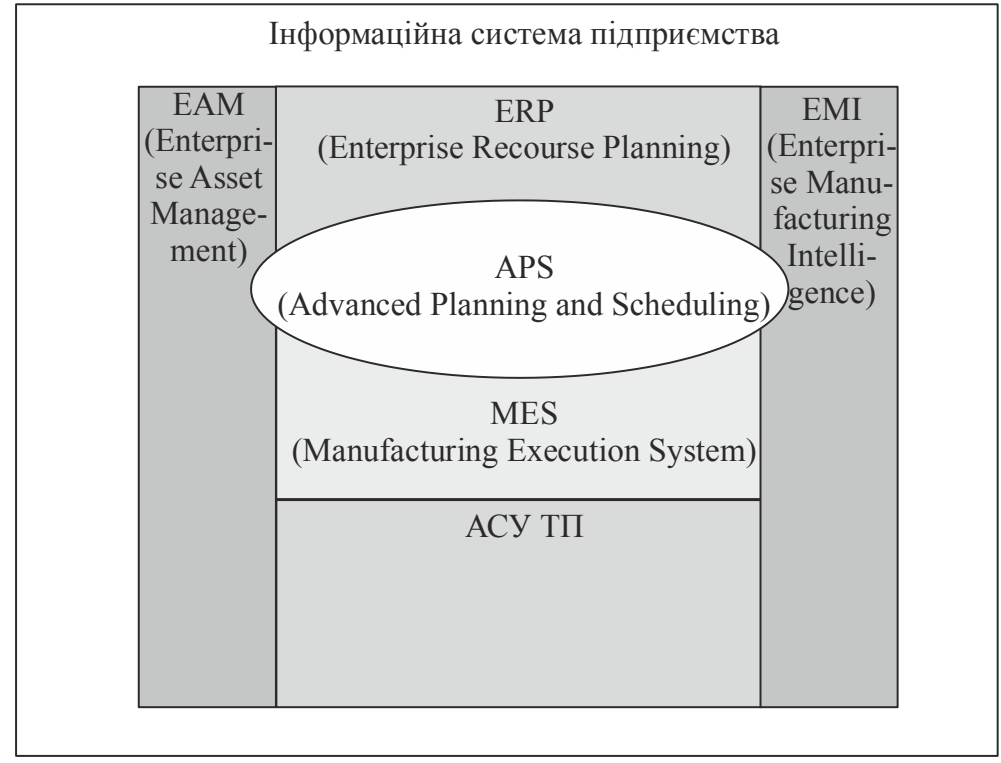

Рис. 2. Структура інформаційної системи підприємства 
Загальні методи та підходи при плануванні. Планування на всіх рівнях керування може проводитися людиною або автоматизовано з використанням точних методів, евристичних методів або їх комбінацією. За останні 30 років теоретичні методи планування набули значного розвитку. Це, очевидно, пов'язано з інтересом до теми з боку промисловості, що, у свою чергу, пов'язано з ринковими викликами та розвитком IT технологій, які відкривають нові можливост реалізації. Найбільш фундаментальною за останні п'ятнадцять років, на наш погляд, працею, присвяченою задачам планування на виробничих підприємствах, є оглядова стаття [10]. Стаття має характер монографії і включає систематизований огляд усіх досягнень попередників, класифікацію задач і методів, що використовуються при плануванні, огляд проблем i перспектив. Цю статтю варто розглядати як навчальний матеріал для молодих науковців, що так чи інакше мають відношення до планування.

Більшість задач на всіх рівнях планування зводяться до змішаного цілочисельного лінійного програмування (MILP, Mixed Integer Linear Programming). Достатньо великий огляд моделей MILP, алгоритмів і застосувань, можливі варіанти покращення моделей і варіантів вирішення, та задачі, які необхідно вирішувати в майбутньому, автори показали у [11; 12]. Зокрема вони виділили такі напрямки: використання MILP на різних рівнях планування як цілісної задачі, вирішення проблеми великої розмірності пов'язаної зі збільшенням номенклатури виробів та обладнання, необхідності перепланування у зв'язку зі зміною виробничої ситуації та замовлень.

Планування в молочному виробництві. Як відмічено вище, планування в молочному виробництві має свої особливості. Систематизовані огляди в цій тематиці нам не зустрічалися, однак спостерігається інтерес до неї. Питання планування були згадані у дисертаційних роботах, виконаних в Національному університеті харчових технологій $[1 ; 14]$, однак це не було темою дослідження. У відкритих джерелах світових видань зустрічаються праці на теми планування як за різними об'єктами дослідження, так і за рівнем планування. Також відрізняються критерії, за якими проводилася пошук оптимального плану. Так, наприклад, у [15] шведські дослідники як основні критерії оптимізації виробництва йогуртів використовували мінімум відходів від переробки молока та миючих продуктів, що значно впливає на екологію довкілля. Для планування послідовностей виробництва різних видів йогуртів були використані евристичні критерії в комбінації з класичними методами оптимізації змішаного цілочисельного програмування. У [16] автори представили математичну модель цеху виробництва молока різної жирності, що включають декілька ліній 3 пастеризаційними установками та фасувальними машинами.

У дослідженні, що описане в [17], оптимізація планування проводилася на верхньому рівні керування з урахуванням керуванням ланцюжком засмолень, що включає в себе всі етапи життєвого циклу продукту. Дослідження показали важливість точності прогнозування та оперативного реагування планування на зміну замовлень і постачань. Це черговий раз підтверджує важливість планування на всіх рівнях керування. 
У [18] автор зосередився на проблемі швидкого визначення мінімального часу виробництва молочної продукції на підприємстві. Слід зазначити, що для задач об' ємного календарного планування наявність аналітичних моделей $€$ дуже важливою, оскільки дає можливість розрахувати середньострокові плани з урахуванням наявних ресурсів (обладнання та персонал).

У [19] вирішувалася задача оперативного планування виробництва різних видів йогуртів з використанням гібридного підходу, що поєднує переваги моделі змішаного цілочисельного програмування та імітаційного моделювання. Атрибути переробки приймаються як фіксовані величини так само, як i в більшості попередніх досліджень, а час операції, який налаштовується до результатів імітаційного моделювання (за рахунок визначення часу роботи, ймовірності аварійних збоїв та часу ремонту), виставляється як стохастичний параметр для реалістичності рішення. Автори переконані, що з практичної точки зору поточна модель може бути розширена для включення в багатоетапне планування виробництва. Лінія йогуртів також розглядалася і в [20;21]. Автори першого дослідження створили математичну модель для об'ємного календарного планування виготовлення йогуртів, основна увага приділялася планування ресурсів фасувальних автоматів. У [21] при формуванні задачі оптимізації виробничого планування використовуються тільки лінійні обмеження, що значно спрощує процес розрахунку.

У [22] досліджувалася проблема планування на виробництві згущеного молока з урахуванням необхідності відстежуваності. Автори запропонували рішення в два етапи - визначення специфікацій для матеріальних потоків і безпосередньо їх планування. Апробацію на одному з підприємств підтвердила ефективність підходу порівняно з ручним плануванням.

У дисертаційній роботі [23] автор пропонує задачу оперативного планування виробництва розв'язувати через взаємопов'язані підзадачі планування виготовлення продукції й обслуговування обладнання. При цьому для вирішення цих підзадач використовується комбінація евристичних і точних методів.

Більшість із наведених вище досліджень зосереджуються на особливостях певних виробництв або навіть підприємств. Це не дивно, тому що підходи до побудови ефективних планів залежать від виробничої структури та особливостей технологічного обладнання. Більш загальні теоретичні відомості щодо методів планування варто шукати в працях, присвячених об'єктам періодичної та напівнеперервної дії, яка в англомовному варіанті має назву «Batch».

На теренах України, як і на території пострадянського простору, досить велику увагу приділяли і приділяють плануванню в машинобудуванні. Хоч на перший погляд може здатися, що між плануванням в машинобудуванні і молочному виробництві не може бути нічого спільного, однак це зовсім не так. Ваtсh-процеси за своєю природою мають неперервно-дискретний характер, тому багато моделей, підходів і способів вирішення можна запозичити 3 планування в машинобудуванні. Так, наприклад, у дисертаційній роботі [24] автор пропонує ієрархічну систему планування, де на кожному рівні застосовуються різні моделі та способи вирішення. 
Метою статті $\epsilon$ огляд способів, методів, підходів і засобів оперативнокалендарного планування (ОКП), що можуть мати місце для молочних підприємств, та можливі шляхи вдосконалення існуючих систем управління.

Викладення основних результатів дослідження. Аналіз наукових джерел дає привід вважати, що багато практичних задач мають принаймні теоретично-обгрунтовані рішення, навіть якщо вони дають наближені, але в той же час швидкі результати. Більшість задач зводиться до вирішення MILP, що передбачає, у свою чергу, певні спрощення, припущення, та введення додаткових обмежень. Найбільш популярним методом оптимізації є дуже відомий метод гілок і меж. Разом з ним часто використовують алгоритми оптимізації, що передбачають імітаційне моделювання (на базі мереж Петрі або інших мережних інтерпретацій діаграм станів), як правило, в комплексі 3 точними методами MILP. Використання імітаційних моделей зі стохастичною складовою дають можливість ще більше наблизити результати моделювання до реальних. Крім того, для ряду об'єктів створити точну аналітичну модель практично неможливо, що може компенсуватися значними спрощеннями в комплексі з імітаційним моделюванням. Велике значення при побудові планів мають евристичні методи на базі теорій масового обслуговування, теорії розкладів тощо.

Задачі, що потребують вирішення при об'ємному плануванні та оперативно-календарному зовсім різні, хоч і взаємопов'язані. Тому для їх вирішення, як правило, використовуються різні підходи.

Пошук оптимальних оперативно-календарних планів для виробничих цехів зі змішаною (мережною) структурою навіть на невеликому інтервалі планування має значні складності. Те саме стосується міжцехових планів, які, по суті, $\epsilon$ «планами» узгодження внутрішньо-цехових планів. Тому в теоретичних дослідженнях очікуються нові результати саме в цих напрямках.

Незважаючи на жваві дослідження в теоретичному напрямку, практична реалізація функцій планування, зазвичай, базується на ручних операціях, евристичних методах або 3 використанням лінійного програмування (для об'ємного планування). Слід відмітити, що будь-які аналітичні розрахунки потребують побудову математичної моделі конкретної виробничої ділянки та всього виробництва. 3 практичної точки зору це означає, що для кожного підприємства повинно проводитися попередні дослідження, а зміна в переконфігуруванні обладнання повністю зведе отриману адекватну модель нанівець. Складається враження, що теорія і практика постійно будуть іти по різні боки.

$€$ ще ряд особливостей, які ускладнюють процеси планування на підприємствах саме 3 виробництвом молочної продукції, як і в принципі на інших підприємствах 3 багаторецептурним виробництвом. Перш за все це гнучкість виробничих ліній та змінна рецептура. Для прикладу, в цеху виготовлення та пакування цільномолочних продуктів може бути декілька десятків танків, в яких може готовитися різні типи продукту. Набір сумішей у танки відбувається через декілька пастеризаторів, що можуть працювати в паралель на різні танки. В цей час ряд танків може вивантажуватися, ряд проходити мийку, в інших - відбуватися процес приготування. Вивантаження, у свою 
чергу, може відбуватися на різні фасувальні автомати, які теж повинні проходити мийку, як і все інше обладнання. І в кожному з танків можуть готуватися різні продукти за своїми рецептурами, що передбачають різний набір операцій. Таку структуру цеху прийнято називати мережною. В цей же час, поряд 3 традиційними цільномолочними продуктами, ринок постійно потребує нових продуктів, що, у свою чергу, приводить до появи нових рецептів зі своїм набором операцій. При такій гнучкій структурі розробити один раз модель, що буде використовуватися для розрахунку оптимального плану, досить проблематично на будь-якому рівні керування.

Другою особливістю $є$ необхідність мийки обладнання. На перший погляд, мийку обладнання можна орієнтовно прирівняти до операцій підготовки машини (як у машинобудуванні). Однак для харчових виробництв зі змінною рецептурою кожен продукт потребує своєї програми мийки. Враховуючи, що мийка відбувається централізовано на одній із станцій СІР, необхідно враховувати використання ії контурів іншим обладнанням цеху (або навіть іншого цеху).

Третьою особливістю є використання бактерій (заквасок) для приготування кисломолочних продуктів, що вносить певну стохастичну складову в процес моделювання.

Наведені вище особливості потребують розробки особливих моделей, принципів планування саме для таких типів виробничих цехів.

Реалізація планування гнучкого виробництва може проводитися 3 використанням стандартів ISA-95 [5-7], ISA-88 [25-27] (та їх аналогів IEC), які описують моделі всіх ресурсів підприємства. Ці стандарти разом 3 рядом інших лежать в основі референтної моделі компонентів Індустрії 4.0 (RAMI 4.0) та вже давно зарекомендували себе на багатьох підприємствах. Відповідно до них, уся інформація про виробниче обладнання міститься в базі даних підприємства (або в цифровому двійнику активу). Ця інформація, окрім властивостей, може включати також тип відношення до іншого обладнання. Іншими словами, вся виробнича модель в системах керування рівнів MOM та ERP, що розроблені з урахуванням наведених стандартів, вже описується в базі даних. Крім обладнання, в системі знаходиться інформація про інші ресурси (активи, матеріали, персонал). Окрім опису формату таблиць 3 даними, існують специфікації B2MML, які стандартизують представлення цих даних при обміні між складовими інтегрованої системи.

У свою чергу, для багаторецептурного виробництва ще з 1995 року використовуються стандарти ISA-88. У ці стандарти закладена ідея відокремлення опису технології від опису та автоматизації обладнання. У системах, побудованих за цими принципами, «технологічна програма» задається в рецепті (а не в керуючій програмі для обладнання) у вигляді таблиці, списку або діаграми (Ганнта, SFC, PFC). Рецепт складається із компонувальних блоків, які, по суті, $\epsilon$ посиланнями на операції або їх частини (етапи), що реалізовані в програмі керування конкретним обладнаннями. Технолог, по суті, складає 3 етапів усю послідовність, коли створює рецепт для нового продукту. Маючи цифрове представлення рецепту та знаючи час виконання кожного етапу, можна розраховувати час операції на кожному обладнанні. 
На нашу думку, використання теоретичних розробок з оперативно-календарного планування разом 3 можливостями ISA-88/95 можуть дати хороші результати в практичному використанні, тому потребують подальшого дослідження.

Ми також вважаємо, що в найближчі десять років слід очікувати нових ідей в плануванні з використанням хмарних технологій (Cloud). Можливість збирати дані (IоT, IIоT) з будь-яких об'єктів у великій кількості та використовувати їх як в аналітиці, так і в навчанні (наприклад, нейромереж) саме по собі є дуже багатообіцяючим. Однак вже сьогодні є і менш амбітні, і більш практичні можливості. Хмарні технології дають можливість використовувати, якщо потрібно, великі обчислювальні ресурси. Іншими словами, складні обчислення можна запустити відразу на кількох сотнях процесорів, при цьому виділивши їх в потрібний момент часу і заплативши саме за час використання. Хмарні сервіси також зменшують «поріг входження» в систем MES/MOM, оскільки потребують закупівлі дорогого ПЗ та наймання великої групи спеціалістів, що дуже важливо для невеликих підприємств. Тому можна буде очікувати наявність сервісів планування для типових об'єктів у хмарі 3 «коробки». Ми не можемо в рамках цієї статті перерахувати всі можливості такого використання, однак очевидно, що це теж потребує додаткових досліджень.

\section{Висновки}

Аналіз діяльності українських підприємств та інформації 3 доступних джерел дає змогу стверджувати:

1. Молочне виробництво багатоасортиментне, а обладнання має мережну виробничу структуру. Сучасне підприємство повинно функціонувати в умовах змінного замовлення з швидкою реакцією (доба) на зміни в ланцюжку постачань та збуту. Для ефективності роботи підприємства в таких умовах потребується точне планування на всіх рівнях керування.

2. Молочні підприємства України автоматизовані за «клаптиковим» принципом, що не дає змогу побудувати ефективну підсистему планування без інтеграції підсистем усіх рівнів.

3. Функціональна структура підприємства відповідно до сучасних стандартів ISA-95 вже має закладені механізми взаємодії між різними рівнями планування.

4. Теоретичні принципи та методи планування досить швидко розвиваються. Найближчим часом очікуються нові результати в дослідженні планування в багаторецептурних виробництвах з мережною структурою виробничих ліній.

5. Найбільш популярними способами планування є використання змішаного цілочисельного програмування (MILP) разом з імітаційним моделюванням на базі стано-орієнтованих моделей та евристичних алгоритмів.

6. Практичне використання в системах керування пророблених теоретичних методів 3 останніх досліджень зустрічається досить рідко. Однією 3 причин є складність побудови математичних моделей для конкретного виробничого підприємства та необхідність в постійній їі корекції. 
У дослідженні пропонується:

1. Як єдину інтеграційну платформу використовувати стандарти ISA-95, які виступають єдиною моделлю всього підприємства і $\epsilon$ носієм всієї необхідної інформації для процесів керування.

2. Систему керування технологічними процесами будувати на базі принципів і моделей ISA-88. Підсистема планування отримуватиме інформацію про тривалість і послідовність операцій з рецепту та прив'язаних до рецептурних етапів посилань на відповідні етапи запланованого обладнання.

3. Як обчислювальний ресурс використовувати хмарні сервіси.

Потребує подальшого дослідження:

1. Теоретична база, математичні моделі для оперативного планування багаторецептурного виробництва з мережною архітектурою обладнання.

2. Розрахунок і вибір критеріїв оптимальності для оперативного планування виробництвом цільномолочної продукції.

3. Принципи розрахунку операцій на основі рецептурних даних.

4. Процедури отримання та перетворення даних з моделей ресурсів і рецептів.

\section{Література}

1.Иикович Э.Л. Методы комплексной автоматизации производства предприятий технологических отраслей: Построение MES Контроль и учет работы производства Сведение материального баланса Календарное планирование Оперативное управление Обслуживание и ремонт оборудования / Э.Л. Ицкович. - Москва : КРАСАНД, 2013. - 232 с.

2. Пупена О.М. Сучасні стандарти інтегрованого керування і шляхи їх впровадження в Україні / О.М. Пупена, І.В. Ельперін, Р.М. Міркевич // Наукові праці Національного університету харчових технологій. - 2017. - Т. 23, № 1. - С. 25-41.

3. Kletti J. Manufacturing Execution Systems - MES / J. Kletti, B. Berres, O. Brauckmann. Berlin : Springer Berlin Heidelberg, 2007. — 276 p.

4. Meyer H. Manufacturing Execution Systems. Optimal Design, Planning, and Deployment / H. Meyer, F. Fuchs, K. Thiel., 2009. — 248 p.

5. Enterprise/Control System Integration. Part 1: Models and Terminology: ANSI/ISA95.00.01-2010. — [Чинний від 2010-01-01]. — USA : International Society of Automation.

6. Enterprise/Control System Integration. Part 3: Activity Models of Manufacturing Operations Management: ANSI/ISA-95.00.03-2013. — [Чинний від 2013-01-01]. — USA : International Society of Automation.

7. Enterprise/Control System Integration. Part 3: Activity Models of Manufacturing Operations Management: ANSI/ISA-95.00.03-2013. — [Чинний від 2013-01-01]. — USA : International Society of Automation.

8. Мауэргаус Ю.Е. Продвинутое планирование и расписание (AP\&S) в производстве и цепочках поставок / Ю.Е. Мауэргаус. - Москва : Экономика, 2012. - 574 с.

9. Фролов Е.Б. MES-системы, как они есть или эволюция систем планирования производства / Е.Б. Фролов, Р.Р. Загидуллин // Металлообрабатывающее оборудование. 2008. — № 10. — C. 31-37.

10. State-of-the-art review of optimization methods for short-term scheduling of batch processes / [A.M. Carlos, C. Jaime, E.G. Ignacio and ets.]. // Computers and Chemical Engineering. — 2006. — \# 30. — P. 913-946.

11. Christodoulos A.F. Mixed Integer Linear Programming in Process Scheduling: Modeling, Algorithms, and Applications / A.F. Christodoulos, L. Xiaoxia. // Annals of Operations Research. - 2005. - \# 139. - P. 131-162.

12. Michael L.P. Scheduling: Theory, Algorithms, and Systems / L. Pinedo Michael. Berlin: Springer Berlin Heidelberg, 2008. - 662 c. 
13. Савчук O.B. Автоматизоване управління багатоасортиментним виробництвом молочної продукції з використанням когнітивного підходу : дис. канд. техн. наук : 05.13.07 / Савчук Ольга Вікторівна — Київ, 2015. — 241 с

14. Лошак T.B. Автоматизоване управління виробництвом багатоасортиментної продукції молокозаводу : дис. канд. техн. наук : 05.13.07 / Лошак Тетяна Віталіївна Київ, 2002. - 288 с.

15. Berlin $J$. A life cycle based method to minimise environmental impact of dairy production through product sequencing / J. Berlin, U. Sonesson, T. Anne-Marie. // 15. — 2007. \# 4. - P. 347-356.

16. Touil A. An MILP Model for Scheduling Multistage, Multiproducts Milk Processing / A. Touil, A. Echchatbi, A. Charkaoui. // IFAC-PapersOnLine. — 2016. — \# 49. — P. 869-874.

17. Heikkilä $O$. Developing the order fulfilment process in dairy industry : thesis / Heikkilä Olli - Helsinki Metropolia University of Applied Sciences, 2017. — 84 p.

18. Koulouris $A$. Estimating analytically the capacity of batch plants with shared equipment: a yoghurt plant case study / Alexandros Koulouris. // Procedia Food Science. - 2011. — \# 1. P. $1792-1798$.

19. Bilgen $B$. Integrated production scheduling and distribution planning in dairy supply chain by hybrid modelling / B. Bilgen, Y. Celebi. // Annals of Operations Research. — 2013. \# 1. - P. 55-82.

20. Kopanos G. Optimal Production Scheduling and Lot-sizing In Yoghurt Production Lines / G. Kopanos, L. Puigjaner, M. Georgiadis. // Computer Aided Chemical Engineering. — 2010. — \# 28. - P. 1153-1158.

21. Doganis $P$. Optimal scheduling in a yogurt production line based on mixed integer linear programming / P. Doganis, H. Sarimveis. // Journal of Food Engineering. — 2007. — \# 2. P. $445-453$.

22. Kilic $O$. Planning and scheduling in process industries considering industry-specific characteristics : thesis PhD / Kilic Onur Alper - University of Groningen, Enschede, 2011. $161 \mathrm{p}$.

23. Farzad P. Resourse optimization techniques in scheduling application to production and maintenance systems : thesis $\mathrm{PhD}$ / Farzad Pargar - University of Oulu, Oulu, 2017. — $96 \mathrm{p}$.

24. Загидуллин P.P. Система оперативно календарного планирования автоматизированного механообрабатывающего мелкосерийного производства на основе комплексных моделей : дис. докт. техн. наук : 05.13.06 / Загидуллин Равиль Рустэмбекович - Москва, 2007. - $451 \mathrm{c}$.

25. Batch Control Part 1: Models and Terminology: ANSI/ISA-88.00.01-2010. — [Чинний від 2010-01-01]. — USA : International Society of Automation.

26. Batch Control Part 2: Data Structures and Guidelines for Languages: ISA-88.00.02-2001 [Чинний від 2001-01-01]. — USA : International Society of Automation.

27. Batch Control Part 3: General and Site Recipe Models and Representation: ISA88.00.03-2003 - [Чинний від 2003-01-01]. — USA : International Society of Automation. 